\title{
Kajian Pelaksanaan Manajemen Berbasis Sekolah Pada Pendidikan Menengah
}

\author{
Suwandi \\ Pusat Penelitian Kebijakan, Balitbang Kemdiknas Jakarta
}

\begin{abstract}
Abstrak: Tujuan penelitian ini adalah untuk mengetahui: 1) gambaran pelaksanaan manajemen berbasis sekolah (MBS) pada pendidikan menengah; 2) kendala-kendala yang dihadapi pihak sekolah dalam pelaksanaan MBS; dan 3) saran-saran atau masukan pihak sekolah agar pelaksanaan MBS berjalan dengan baik. Penelitian ini menggunakan desain penelitian pengembangan. Pengumpulan data dilakukan dengan menggunakan teknik kuesioner (angket), observasi, dokumentasi, wawancara dan focus group discussions (FGD). Hasil penelitian menunjukkan bahwa: dapat diambil kesimpulan: 1) pelaksanaan MBS di sekolah menengah secara umum berjalan dengan baik; 2) kendala pelaksanaan MBS yang paling menonjol yaitu terbatasnya anggaran biaya, minimnya fasilitas yang dimiliki sekolah, serta masih rendahnya kualitas SDM; dan 3) Saran yang cukup menonjol dari pihak sekolah adalah agar pemerintah (pusat dan daerah) dapat meningkatkan bantuan/subsidi keuangan berupa dana block grant, dekonsentrasi (termasuk BOS/BKM), dana dari Depag, APBD Provinsi dan APBD Kota/Kabupaten. masih layak diterapkan untuk penyaluran dana pendidikan di sekolah dengan beberapa pembenahan, terutama dalam pemberdayaan Dinas Pendidikan Provinsi dan Dinas Pendidikan Kabupaten/Kota.
\end{abstract}

Kata kunci: sekolah menengah, manajemen sekolah, dan mutu

\begin{abstract}
The Objective of this research is to find out: 1) The illustration of school base management implementation on the secondary school; 2) The obstacles in school based management implementation experienced by schools; 3) Suggestion from school in order to implement school based management better. Data was collected from a questionnaire, observation, documentation, interview, and Focus Group Discussions (FGD). From the result, it is concluded that: 1) Generally, school based management implementation in schools has run well; 2 )The main issues in school based management implementation are lack of budget, minimum facility, incompetent human resources; and 3) The major suggestion from schools is that the center and local government increase the budget subsidy derives from block grant, deconcentration fund (including BOS/BKM), Ministry of Religious Affair, Provincial and regency budget for the distribution of educational budget to schools with some improvements particulary in the empowerment of provincial and regency educational offices.
\end{abstract}

Key words: secondary school, school management, and quality

\section{Pendahuluan}

Permasalahan sekitar rendahnya mutu penyelenggaraan pendidikan di Indonesia selama ini pada dasarnya bermuara pada lemahnya pengelolaan, pengorganisasian dan pengembangan institusi. Sebagaimana diidentifikasi oleh Bank Dunia (1998), bahwa ada empat unsur yang menjadi penghambat potensial terhadap kemajuan pendidikan di Indonesia, yaitu: a) sistem organisasi yang kompleks di tingkat pendidikan (sekolah); b) manajemen yang terlalu sentralistik; c) terpecah-belah dan kakunya proses pembiayaan; dan d) manajemen yang tidak efektif.
Pertama, kompleks pengorganisasian pendidikan, dimana terjadi dualisme pengorganisasian dan pengadministrasian pendidikan. Depdiknas mengelola dan bertanggung jawab pada materi pendidikan dan mutu teknis seperti kurikulum, kualifikasi dan sertifikasi guru, testing dan evaluasi pembelajaran; sedangkan Depdagri mengelola dan bertanggung jawab atas ketenagaan, material, dan sumber daya lainnya. Dualisme pengelolaan ini berakibat fatal, karena membuat rancunya pembagian tanggung jawab dan peranan manajerial, keterlambatan dan terpilahpilahnya sistem perencanaan dan pembiayaan, 
serta perebutan kewenangan atas guru antara kedua lembaga tersebut.

Kedua, praktik manajemen pendidikan oleh Depdiknas yang teralu sentralistik, sangat menghambat pencapaian tujuan pendidikan. Praktik seperti ini mengakibatkan perluasan kesempatan dan cara kerja yang efisien pada jenjang pendidikan menjadi sulit terwujud.

Ketiga, terpecah-belah dan kakunya proses pembiayaan, di samping menyebabkan kompleksnya organisasi, juga menambah rumitnya pengelolaan pendidikan. Anggaran pembangunan (DIP) disiapkan oleh Bappenas, Depdiknas, dan Depdagri, sedangkan anggaran rutin (DIK) disiapkan oleh Depkeu, Depdiknas, dan Depdagri. Dalam praktiknya, masing-masing anggaran mempunyai aturannya sendiri sehingga yang terjadi antara lain, perencanaan, kaji-ulang, dan persetujuan anggaran yang memakan waktu satu tahun. Praktik seperti ini memiliki dampak negatif, antara lain tidak ada tanggung jawab yang jelas antar unit, tidak ada evaluasi secara regular terhadap kebutuhan riel yang diperlukan, dan tidak ada jaminan bahwa dana benar-benar dialokasikan berdasarkan asas pemerataan.

Keempat, manajemen pada tingkat sekolah tidak efektif, yang diindikasikan oleh sangat terbatasnya otonomi kepala sekolah dalam mengelola sumber daya dan manajemen sekolah. Kepala sekolah juga tidak dilengkapi dengan kemampuan kepemimpinan manajerial yang baik, karena pada umumnya hanya dibekali beberapa hari pelatihan, rekrutmen mereka lebih didasarkan atas urutan jenjang kepangkatan.

Rahma Sugihartati (2004: 3) menjelaskan bahwa dalam konteks pengelolaan tingkat sekolah, upaya meningkatkan mutu pendidikan harus lebih difokuskan pada peningkatan pengelolaan sekolah agar menjadi efektif, melalui apa yang dikenal dengan manajemen berbasis sekolah (MBS). MBS adalah bentuk alternatif sekolah sebagai hasil dari desentralisasi dalam bidang pendidikan. Sebagai wujud dari reformasi pendidikan, MBS pada prinsipnya bertumpu pada sekolah dan masyarakat serta jauh dari birokrasi yang sentralistik. MBS berpotensi untuk meningkatkan partisipasi masyarakat, pemerataan, efisiensi, serta manajemen yang bertumpu pada tingkat sekolah. Penerapan MBS secara efektif, diharapkan mengurangi kontrol pemerintah pusat, dan di pihak lain semakin meningkatnya otonomi sekolah untuk menentukan sendiri apa yang perlu diajarkan dan mengelola sumber daya yang ada untuk berinovasi.

Lebih lanjut dijelaskan bahwa, sejalan dengan kebijakan desentralisasi pendidikan yang dilaksanakan pemerintah sejak tahun 1999, telah dilaksanakan program pengelolaan sekolah yang memberikan otonomi lebih besar kepada sekolah dan mendorong sekolah untuk melakukan pengambilan keputusan secara partisipatif untuk memenuhi kebutuhan mutu sekolah atau untuk mencapai tujuan mutu sekolah dalam kerangka pendidikan nasional. Program ini disebut sebagai manajemen berbasis sekolah (MBS). Esensi MBS adalah pemberian otonomi sekolah dan pengambilan keputusan secara partisipatif dalam pengelolaan unsur-unsur manajemen sekolah yang didesentralisasi di tingkat sekolah.

Dalam konteks operasional pengelolaan sekolah, Indarno (2002: 22) menjelaskan bahwa setidaknya terdapat tiga kondisi yang menyebabkan manajemen sekolah tidak efektif, yaitu: a) pada umumnya kepala sekolah (khususnya sekolah negeri) memiliki otonomi yang sangat terbatas dalam mengelola sekolahnya atau dalam memutuskan pengalokasian sumber daya sekolah; b) pada sisi kepala sekolah sendiri, mereka kurang memiliki keterampilan untuk mengelola sekolah dengan baik; c) kecilnya peran serta masyarakat dalam pengelolaan sekolah, padahal perolehan dukungan dari masyarakat merupakan bagian dari peran kepemimpinan kepala sekolah.

Mendasarkan kepada tiga kondisi riel tersebut, unsur-unsur manajemen yang didesentralisasikan dalam konteks manajemen peningkatan mutu berbasis sekolah meliputi empat hal pokok, yang didalamnya mencakup beberapa aspek: pertama, unsur pengelolaan partisipasi masyarakat; kedua, unsur pengelolaan ketenagaan, mencakup: kepala sekolah, guru, siswa, pengawas, tenaga laboratorium, tenaga perpustakaan, dan tata usaha sekolah; ketiga, unsur pengelolaan keuangan, mencakup: dana DIK, dana DIP (BOP/ OPF), block grant, dan dana dari masyarakat; dan keempat, pengelolaan kurikulum dan pembelajaran, mencakup: materi; pengujian, tes dan 
evaluasi; buku dan alat bantu pembelajaran; dan sarana dan prasarana pembelajaran.

Keempat hal pokok di atas, telah diimplementasikan sebagai program manajemen berbasis sekolah (MBS) sejak tahun 1999. Untuk mengetahui hasil-hasil penerapan program tersebut sangat perlu dilakukan evaluasi terhadap komponen dan indikator pencapaian program; serta yang lebih pokok adalah mengetahui dampak penerapan program terhadap unsurunsur manajemen yang telah didesentralisasikan di tingkat sekolah.

Berdasarkan latar belakang di atas, permasalahan yang akan diungkap dalam penelitian ini adalah: Bagaimanakah pelaksanaan manajemen berbasis sekolah pada pendidikan menengah yang telah berjalan selama ini? Kendala-kendala apa sajakah yang ditemui pihak sekolah (kepala sekolah, guru, tenaga administrasi) dalam pelaksanaan manajemen berbasis sekolah pada pendidikan menengah? Bagaimanakah saransaran dari pihak sekolah (kepala sekolah, guru, tenaga administrasi) agar pelaksanaan manajemen berbasis sekolah berjalan dengan baik?

\section{Kajian Teori Konsep MBS}

Model pendekatan dalam manajemen sekolah mengacu pada manajemen berbasis sekolah (school based management) atau disingkat MBS. Di mancanegara, seperti Amerika Serikat, pendekatan ini sebenarnya telah berkembang cukup lama. Pada 1988 American Association of School Administrators, National Association of Elementary School Principals, and National Association of Secondary School Principals, menerbitkan dokumen berjudul school based management, a strategy for better learning. Munculnya gagasan ini dipicu oleh ketidakpuasan atau kegerahan para pengelola pendidikan pada level operasional atas keterbatasan kewenangan yang mereka miliki untuk dapat mengelola sekolah secara mandiri (Daman, 2001: 3).

Selanjutnya Daman menjelaskan bawa di Indonesia, gagasan penerapan pendekatan ini muncul belakangan sejalan dengan pelaksanaan otonomi daerah sebagai paradigma baru dalam pengoperasian sekolah. Selama ini, sekolah hanyalah kepanjangan tangan birokrasi pemerintah pusat untuk menyelenggarakan urusan politik pendidikan. Para pengelola sekolah sama sekali tidak memiliki banyak kelonggaran untuk mengoperasika sekolahnya secara mandiri. Semua kebijakan tentang penyelenggaraan pendidikan di sekolah umumnya diadakan di tingkat pemerintah pusat atau sebagian di instansi vertikal dan sekolah hanya menerima apa adanya.

MBS adalah upaya serius yang rumit, yang memunculkan berbagai isu kebijakan dan melibatkan banyak lini kewenangan dalam pengambilan keputusan serta tanggung jawab dan akuntabilitas atas konsekuensi keputusan yang diambil. Oleh sebab itu, semua pihal yang terlibat perlu memahami benar pengertian MBS, manfaat, masalah-masalah dalam penerapannya, dan yang terpenting adalah pengaruhnya terhadap prestasi belajar murid (Hamonangan, 2004: 34).

Selanjutnya Hamonangan menjelaskan, secara umum, manajemen peningkatan mutu berbasis sekolah (MBS) dapat diartikan sebagai model manajemen yang memberikan otonomi lebih kepada sekolah, memberikan fleksibilitas/ keluwesan-keluwesan kepada sekolah, dan mendorong partisipasi secara langsung warga sekolah (guru, siswa, kepala sekolah, karyawan) dan masyarakat (orangtua siswa, tokoh masyarakat, ilmuwan, pengusaha, dan sebagainya) untuk meningkatakan mutu sekolah berdasarkan kebijakan pendidikan nasional serta peraturan perundang-undangan yang berlaku (Catatan: MBS tidak dibenarka menyimpang dari peraturan perundang-undangan yang berlaku).

Pada sisi yang lain, Indarno (2002: 8) menjelaskan bahwa, MBS juga merupakan salah satu wujud dari reformasi pendidikan yang menawarkan kepada sekolah untuk menyediakan pendidikan yang lebih baik dan memadai bagi siswa. Hal ini juga berpotensi untuk meningkatkan kinerja staf, menawarkan partisipasi langsung kepada kelompok-kelompok terkait, dan meningkatkan pemahaman kepada masyarakat terhadap pendidikan.

Lebih lanjut dijelaskan bahwa MBS merupakan suatu konsep yang menempatkan kekuasaan pengambilan keputusan yang berkaitan dengan pendidikan diletakkan pada tempat yang paling 
dekat dengan proses belajar mengajar. Tujuan utama penerapan MBS pada intinya adalah untuk penyeimbangan struktur kewenangan antara sekolah, pemerintah daerah pelaksanaan proses dan pusat sehingga manajemen menjadi lebih efisien. Kewenangan terhadap pembelajaran diserahkan kepada unit yang paling dekat dengan pelaksanaan proses pembelajaran itu sendiri yaitu sekolah.

\section{MBS dan Sekolah Efektif}

MBS memiliki karakteristik yang perlu dipahami oleh sekolah yang akan menerapkannya. Dengan kata lain, jika sekolah ingin sukses dalam menerapkan MBS, maka sejumlah karakteristik MBS berikut perlu dimiliki. Berbicara karakteristik MBS tidak dapat dipisahkan dengan karakteristik sekolah efektif. Jika MBS merupakan wadah/ kerangkanya, maka sekolah efektif merupakan isinya. Oleh karena itu, karakteristik MBS berikut memuat secara inklusif elemen-elemen sekolah efektif, yang dikategorikan menjadi input, proses, dan output (Jaelani dan Kuntoro, 2005: 11).

Selanjutnya Jaelani dan Kuntoro menjelaskan bahwa dalam menguraikan karakteristik MBS, pendekatan sistem yaitu input-proses-output digunakan untuk memandunya. Hal ini didasari oleh pengertian bahwa sekolah merupakan sebuah sistem, sehingga penguraian karakteristik MBS (yang juga karakteristik sekolah efektif) mendasarkan pada input, proses, dan output.

\section{Input Pendidikan}

Input pendidikan terdiri atas: a) Memiliki Kebijakan, Tujuan, dan Sasaran Mutu yang jelas. Secara formal, sekolah menyatakan dengan jelas tentang keseluruhan kebijakan, tujuan, dan sasaran sekolah yang berkaitan dengan mutu. Kebijakan, tujuan, dan sasaran mutu tersebut dinyatakan oleh kepala sekolah. Kebijakan, tujuan, dan sasaran mutu tersebut disosialisasikan kepada semua warga sekolah, sehingga tertanam pemikiran, tindakan, kebiasaan, hingga sampai pada kepemilikan karakter mutu oleh warga sekolah; b) Sumberdaya Tersedia dan Siap, sumberdaya merupakan input penting yang diperlukan untuk berlangsungnya proses pendidikan di sekolah. Tanpa sumberdaya yang memadai, proses pendidikan di sekolah tidak akan berlangsung secara memadai, dan pada gilirannya sasaran sekolah tidak akan tercapai. Sumberdaya dapat dikelompokkan menjadi dua, yaitu sumberdaya manusia dan sumberdaya selebihnya (uang, peralatan, perlengkapan, bahan, dan sebagainya) dengan penegasan bahwa sumberdaya selebihnya tidak mempunyai arti apapun bagi perwujudan sasaran sekolah, tanpa campur tangan sumberdaya manusia; c) Staf yang Kompeten dan Berdedikasi Tinggi, meskipun pada butir (b) telah disinggung tentang ketersediaan dan kesiapan sumberdaya manusia (staf), namun pada butir ini perlu ditekankan lagi karena staf merupakan jiwa sekolah. Sekolah yang efektif pada umumnya memiliki staf yang mampu (kompeten) dan berdedikasi tinggi terhadap sekolahnya. Implikasinya jelas, yaitu bagi sekolah yang ingin efektivitasnya tinggi, maka kepemilikan staf yang kompeten dan berdedikasi tinggi merupakan keharusan; d) Memiliki Harapan Prestasi yang Tinggi, sekolah yang menerapkan MBS mempunyai dorongan dan harapan yang tinggi untuk meningkatkan prestasi peserta didik dan sekolahnya. Kepala sekolah memiliki komitmen dan motivasi yang kuat untuk meningkatkan mutu sekolah secara optimal. Guru memiliki komitmen dan harapan yang tinggi bahwa anak didiknya dapat mencapai tingkat prestasi yang maksimal, walaupun dengan segala keterbatasan sumberdaya pendidikan yang ada di sekolah; e) Fokus pada Pelanggan (Khususnya Siswa), Pelanggan, terutama siswa, harus merupakan fokus dari semua kegiatan sekolah. Artinya, semua input dan proses yang dikerahakn di sekolah tertuju utamanya untuk meningkatkan mutu dan kepuasan peserta didik. Konsekuensi logis dari ini semua adalah bahwa penyiapan input dan proses belajar mengajar harus benarbenar mewujudkan sosok utuh mutu dan kepuasan yang diharapkan dari siswa; f) Input Manajemen, sekolah yang menerapkan MBS memiliki input manajemen yang memadai untuk menjalankan roda sekolah. Kepala sekolah dalam mengatur dan mengurus sekolahnya menggunakan sejumlah input manajemen. Kelengkapan dan kejelasan input manajemen akan membantu kepala sekolah mengelola sekolahnya dengan efektif. Input manajemen yang dimaksud meliputi: tugas yang jelas, rencana yang rinci dan 
sistematis, program yang mendukung bagi pelaksanaan rencana, ketentuan-ketentuan (aturan main) yang jelas sebagai panutan bagi warga sekolahnya untuk bertindak, dan adanya sistem pengendalian mutu yang efektif dan efisien untuk meyakinkan agar sasaran yang telah disepakati dapat dicapai (Jaelani dan Kuntoro, 2005: 12-14).

\section{Proses}

Menurut Rahma Sugihartati (2004: 15) sekolah yang efektif pada umumnya memiliki sejumlah karakteristik proses sebagai berikut: a) Proses Belajar Mengajar yang Efektivitasnya Tinggi, sekolah yang menerapkan MBS memiliki efektivitas proses belajar mengajar (PBM) yang tinggi. Ini ditunjukkan oleh sifat PBM yang menekankan pada pemberdayaan peserta didik. PBM bukan sekedar memorisasi dan recall, bukan sekedar penekanan pada penguasaan pengetahuan tentang apa yang diajarkan (logos), akan tetapi lebih menekankan pada internalisasi tentang apa yang diajarkan sehingga tertanam dan berfungsi sebagai muatan nurani dan dihayati (ethos) serta dipraktekkan dalam kehidupan sehari-hari oleh peserta didik (pathos); b) Kepemimpinan Sekolah yang Kuat, pada sekolah yang menerapkan MBS, kepala sekolah memiliki peran yang kuat dalam mengkoordinasikan, menggerakkan, dan menyerasikan semua sumberdaya pendidikan yang tersedia. Kepemimpinan kepala sekolah merupakan salah satu faktor yang dapat mendorong sekolah untuk dapat mewujudkan visi, misi, tujuan, dan sasaran sekolahnya melalui program-program yang dilaksanakan secara terencana dan bertahap; c) Lingkungan Sekolah yang Aman dan Tertib, sekolah memiliki lingkungan (iklim) belajar yang aman, tertib, dan nyaman sehingga proses belajar mengajar dapat berlangsung dengan nyaman (enjoyable learning). Karena itu, sekolah yang efektif selalu menciptakan iklim sekolah yang aman, nyaman, tertib melalui pengupayaan faktor-faktor yang dapat menumbuhkan iklim tersebut. Dalam hal ini, peranan kepala sekolah sangat penting sekali; d) Pengelolaan Tenaga Kependidikan yang Efektif, tenaga Kependidikan, terutama guru, merupakan jiwa dari sekolah. Sekolah hanyalah merupakan wadah. Sekolah yang menerapka
MPMBS menyadari tentang hal ini. Oleh karena itu, pengelolaan tenaga kependidikan, mulai dari analisis kebutuhan, perencanaan, pengembangan, evaluasi kinerja, hubungan kerja, hingga sampai pada imbal jasa, merupakan garapan penting bagi seorang kepala sekolah; e) Sekolah Memiliki Budaya Mutu, budaya mutu tertanam di sanubari semua warga sekolah, sehingga setiap perilaku selalu didasari oleh profesionalisme. Budaya mutu memiliki elemen-elemen sebagai berikut: (a) informasi kualitas harus digunakan untuk perbaikan, bukan untuk mengadili/ mengontrol orang; (b) kewenangan harus sebatas tanggung jawab; (c) hasil harus diikuti penghargaan (rewards) atau sanksi (punishment); (d) kolaborasi dan sinergi, bukan kompetisi, harus merupakan basis untuk kerjasama; (e) warga sekolah merasa aman terhadap pekerjaannya; (f) atmosfir keadilan (fairness) harus ditanamkan; (g) imbal jasa harus sepadan dengan nilai pekerjaannya; dan (h) warga sekolah merasa memiliki sekolah; f) Sekolah Memiliki "Teamwork" yang Kompak, Cerdas, dan Dinamis, Kebersamaan (teamwork) merupakan karakteristik yang dituntut oleh MBS, karena output pendidikan merupakan hasil kolektif warga sekolah, bukan hasil individual. Karena itu, budaya kerjasama antar fungsi dalam sekolah, antar individu dalam sekolah, harus merupakan kebiasaan hidup sehari-hari warga sekolah; g) Sekolah Memiliki Kewenangan (Kemandirian), sekolah memiliki kewenangan untuk melakukan yang terbaik bagi sekolahnya, sehingga dituntut untuk memiliki kemampuan dan kesanggupan kerja yang tidak selalu menggantungkan pada atasan. Untuk menjadi mandiri, sekolah harus memiliki sumberdaya yang cukup untuk menjalankan tugasnya; h) Partisipasi yang Tinggi dari Warga Sekolah dan Masyarakat, sekolah yang menerapkan MBS memiliki karakteristik bahwa partisipasi warga sekolah dan masyarakat merupakan bagian kehidupannya. Hal ini dilandasi oleh keyakinan bahwa makin tinggi tingkat partisipasi, makin besar rasa memiliki; makin besar rasa memiliki, makin besar pula rasa tanggungjawab, dan makin besar rasa tanggungjawab, makin besar pula tingkat dedikasinya; i) Sekolah Memiliki Keterbukaan (Transparansi) Manajemen, keterbukaan/transparansi dalam pengelolaan 
sekolah merupakan karakteristik sekolah yang menerapkan MBS. Keterbukaan/transparansi ini ditunjukkan dalam pengambilan keputusan, perencanaan dan pelaksanaan kegiatan, penggunaan uang, dan sebagainya, yang selalu melibatkan pihak-pihak terkait sebagai alat kontrol; j) Sekolah Memiliki Kemauan untuk Berubah (Psikologis dan pisik), perubahan harus merupakan sesuatu yang menyenangkan bagi semua warga sekolah. Sebaliknya, kemapanan merupakan musuh sekolah. Tentu saja yang dimaksud perubahan adalah peningkatan, baik bersifat fisik maupun psikologis. Artinya, setiap dilakukan perubahan, hasilnya diharapkan lebih baik dari sebelumnya (ada peningkatan) terutama mutu peserta didik; k) Sekolah Melakukan Evaluasi dan Perbaikan secara Berkelanjutan, evaluasi belajar secara teratur bukan hanya ditujukan untuk mengetahui tingkat daya serap dan kemampuan peserta didik, tetapi yang terpenting adalah bagaimana memanfaatkan hasil evaluasi belajar tersebut untuk memperbaiki dan menyempurnakan proses belajar mengajar di sekolah. Oleh karena itu, fungsi evaluasi menjadi sangat penting dalam rangka meningkatkan mutu peserta didik dan mutu sekolah secara keseluruhan dan secara terus menerus; I) Sekolah Responsif dan Antisipatif terhadap Kebutuhan, sekolah selalu tanggap/ responsif terhadap berbagai aspirasi yang muncul bagi peningkatan mutu. Karena itu, sekolah selalu membaca lingkungan dan menanggapinya secara cepat dan tepat. Bahkan, sekolah tidak hanya mampu menyesuaikan terhadap perubahan/tuntutan, akan tetapi juga mampu mengantisipasi hal-hal yang mungkin bakal terjadi. Menjemput bola, adalah padanan kata yang tepat bagi istilah antisipatif; m) Memiliki Komunikasi yang Baik, sekolah yang efektif umumnya memiliki komunikasi yang baik, terutama antar warga sekolah, dan juga sekolahmasyarakat, sehingga kegiatan-kegiatan yang dilakukan oleh masing-masing warga sekolah dapat diketahui. Dengan cara ini, maka keterpaduan semua kegiatan sekolah dapat diupayakan untuk mencapai tujuan dan sasaran sekolah yang telah dipatok. Selain itu, komunikasi yang baik juga akan membentuk teamwork yang kuat, kompak, dan cerdas, sehingga berbagai kegiatan sekolah dapat dilakukan secara merata oleh warga sekolah; n) Sekolah Memiliki Akuntabilitas, akuntabilitas adalah bentuk pertanggungjawaban yang harus dilakukan sekolah terhadap keberhasilan program yang telah dilaksanakan. Akuntabilitas ini berbentuk laporan prestasi yang dicapai dan dilaporkan kepada pemerintah, orangtua siswa, dan masyarakat. Berdasarkan laporan hasil program ini, pemerintah dapat menilai apakah program MBS telah mencapai tujuan yang dikehendaki atau tidak. Jika berhasil, maka pemerintah perlu memberikan penghargaan kepada sekolah yang bersangkutan, sehingga menjadi faktor pendorong untuk terus meningkatkan kinerjanya di masa yang akan datang. Sebaliknya jika program tidak berhasil, maka pemerintah perlu memberikan teguran sebagai hukuman atas kinerjany yang dianggap tidak memenuhi syarat; o) Sekolah memiliki Kemampuan Menjaga Sustainabilitas, sekolah yang efektif juga memiliki kemampuan untuk menjaga kelangsungan hidupnya (sustainabilitasnya) baik alam program maupun pendanaannya. Sustainabilitas program dapat dilihat dari keberlanjutan program-program yang telah dirintis sebelumnya dan bahkan berkembang menjadi program-program baru yang belum pernah ada sebelumnya.

\section{Output yang Diharapkan}

Sekolah harus memiliki output yang diharapkan. Output sekolah adalah prestasi sekolah yang dihasilkan oleh proses pembelajaran dan manajemen di sekolah. Pada umumnya, output dapat diklasifikasikan menjadi dua, yaitu output berupa prestasi akademik (academic achievement) dan output berupa prestasi non-akademik (nonacademic achievement). Output prestasi akademik misalnya, NEM, lomba karya ilmiah remaja, lomba (Bahasa Inggris, Matematika, Fisika), cara-cara berpikir (kritis, kreatif/divergen, nalar, rasional, induktif, dedukatif, dan ilmiah) (Sallis, 1993: 12).

\section{Metode Penelitian}

Penelitian ini menggunakan pendekatan dengan memodifikasi desain penelitian pengembangan. Populasi penelitian ini yaitu sekolah menengah negeri dan swasta di seluruh wilayah Indonesia yang kepala sekolahnya telah mendapatkan 
penataran secara formal MBS. Sampel dalam penelitian ini diambil secara purposive di 5 provinsi yang terdiri atas 2 (dua) provinsi dari pulau Jawa, yaitu Jawa Timur, dan Daerah Istimewa Yogyakarta, 3 (tiga) provinsi di luar Jawa, yaitu Sumatera Selatan, Sulawesi Selatan, dan Kalimantan Timur. Pemilihan sekolah sebagai sampel juga memperhatikan jenis dan status sekolah. Jenis sekolah meliputi SMA (Sekolah Menengah Atas) dan SMK (Sekolah Menengah Kejuruan), sedangkan status sekolah meliputi sekolah negeri maupun swasta. Tiap provinsi dipilih dua wilayah kabupaten, dimana masingmasing kabupaten diwakili oleh 6 sekolah. Berdasarkan status sekolahnya, 6 sekolah tersebut terdiri dari 4 sekolah negeri dan 2 sekolah swasta, sedangkan apabila dipilah menurut jenisnya, terdiri dari 4 SMA dan 2 SMK. Jadi, jumlah seluruh sekolah adalah 6 sekolah $\times 2$ kabupaten $\times 5$ provinsi $=60$ sekolah. Setiap sekolah dipilih tiga responden, yaitu kepala sekolah, guru, dan kepala tata usaha, jadi jumlah responden seharusnya $3 \times 60=180$. Dalam pelaksanaan pengumpulan data di lapangan, terdapat berbagai kendala baik teknis maupun non teknis sehingga jumlah maupun sebaran sumber data atau responden tidak sepenuhnya sesuai dengan rancangan awal. Namun demikian secara garis besar sumber data yang masuk tidak menyimpang jauh dari rancangan awal, sehingga tahapan penelitian selanjutnya dapat dilakukan.

Pengumpulan data dilakukan dengan menggunakan teknik kuisioner (angket), observasi, dokumentasi, wawancara dan focus group discussion (FGD). Data yang berasal dari angket dengan jawaban tertutup (pilihan ganda) digunakan teknik analisis deskriptif-kualitatif. Pada analisis deskriptif, dilakukan perhitungan dengan sajian persentase (\%).

\section{Hasil Penelitian dan Pembahasan \\ Perencanaan dan Evaluasi Sekolah Pelaksanaan}

Terdapat tiga item pertanyaan untuk mengungkap bagaimana pelaksanaan perencanaan dan evaluasi sekolah. Berdasarkan analisis deskriptif persentase, dapat diketahui bahwa rerata persentasenya $83,55 \%$ atau termasuk kategori baik. Jika dilihat rerata persentase di antara ketiga item maupun di antara responden (kepala sekolah, guru, tata usaha), perbedaan yang ada juga tidak terlalu mencolok.

Tabel 1. Deskriptif Persentase Perencanaan dan Evaluasi Sekolah

\begin{tabular}{|l|r|r|r|r|}
\hline $\begin{array}{l}\text { No. } \\
\text { Item }\end{array}$ & Kepsek & Guru & TU & Rerata \\
\hline 1 & $89.41 \%$ & $88.14 \%$ & $86.44 \%$ & $87.29 \%$ \\
2 & $82.63 \%$ & $80.08 \%$ & $80.93 \%$ & $80.51 \%$ \\
3 & $84.32 \%$ & $82.63 \%$ & $83.05 \%$ & $82.84 \%$ \\
\hline Rerata & $85.45 \%$ & $83.62 \%$ & $83.47 \%$ & $83.55 \%$ \\
\hline
\end{tabular}

Kendala umum yang dihadapi dalam perencanaan dan evaluasi sekolah adalah terkait dengan keterbatasan dana atau anggaran. Hampir $80 \%$ responden mengungkapkan bahwa untuk melaksanakan perencanaan sesuai kebutuhan (school based plan) terkendala masalah dana, baik yang bersumber dari pemerintah maupun orang tua siswa. Kendala lain yang terungkap adalah menyangkut kualitas SDM di sekolah yang rendah. Berdasarkan kendalakendala di atas, terdapat beberapa saran yang dikemukakan pihak sekolah (kepala sekolah, guru, tenaga administrasi), antara lain: 1) Pemerintah perlu meningkatkan bantuan atau subsidi bagi sekolah, baik sekolah negeri maupun swasta, misalnya dalam bentuk block grant, 2) perlu adanya pelatihan-pelatihan di berbagai bidang keahlian, utamanya yang terkait dengan perencanaan dan evaluasi sekolah, bagi kepala sekolah maupun guru (in service training) sehingga kualitas SDM sekolah meningkat, 3) semua pihak harus bersikap jujur, transparan (terbuka), menerima kekurangan-kekurangan atau kritik-kritik, serta 4) perlu ditekankan adanya tindak lanjut dari hasil evaluasi yang telah dilakukan sebelumnya.

\section{Pengelolaan Kurikulum Pelaksanaan}

Pengelolaan kurikulum pada sekolah juga termasuk dalam kategori baik, hal ini ditunjukkan dengan rerata persentase sebesar $78,60 \%$. Persentase ini sedikit lebih rendah daripada rerata persentase aspek perencanaan dan evaluasi sekolah. Dari dua item pertanyaan yang ada, rerata persentase item nomor 5 relatif lebih 
rendah. Jika ditelusuri, item nomor 5 berisi tentang pelaksanaan pengembangan kurikulum muatan lokal. Hasil lengkap analisis dapat dilihat pada tabel 2 .

Tabel 2. Deskriptif Persentase Pengelolaan Kurikulum

\begin{tabular}{|l|r|r|r|r|}
\hline $\begin{array}{l}\text { No. } \\
\text { Item }\end{array}$ & Kepsek & Guru & TU & Rerata \\
\hline 4 & $80.51 \%$ & $80.51 \%$ & $80.93 \%$ & $80.72 \%$ \\
3 & $75.85 \%$ & $76.69 \%$ & $76.27 \%$ & $76.48 \%$ \\
\hline Rerata & $78.18 \%$ & $78.60 \%$ & $78.60 \%$ & $78.60 \%$ \\
\hline
\end{tabular}

Kendala-kendala yang dihadapi berkaitan dengan pengelolaan kurikulum antara lain adalah: 1) anggaran biaya atau fasilitas pendidikan yang terbatas atau kurang mencukupi, 2) guru mengajar tidak sesuai dengan bidang keahlian atau latar belakang pendidikannya, 3) kemampuan atau kompetensi guru kurang/tidak sesuai dengan yang diharapkan, serta 4) sumber/bahan ajar terbatas atau sulit diperoleh. Beberapa saran yang dikemukakan pihak sekolah adalah: 1) perlu adanya bimbingan teknis (Bintek) tentang pelaksanaan Kurikulum Tingkat Satuan Pendidikan (KTSP), 2) workshop pengembangan kurikulum, 3) rekrutmen tenaga pendidik/guru agar sesuai dengan bidang keahlian yang dibutuhkan, serta 4) perlu adanya penambahan bantuan fasilitas serta buku-buku yang dibutuhkan sekolah.

\section{Pengelolaan Proses Belajar Mengajar Pelaksanaan}

Pelaksanaan proses belajar mengajar (PBM) pada sekolah secara umum berjalan dengan baik, dengan rerata persentase $80,40 \%$. Pada item no. 6 tentang kebebasan memilih strategi atau metode pembelajaran yang sesuai dengan karakteristik peserta didik, guru, dan kondisi nyata sumberdaya yang ada di sekolah, jawaban kepala sekolah dan guru termasuk kategori sangat baik (> 85\%), yaitu masing-masing sebesar 91,53\% dan $88,56 \%$. Pada item no.7, persentase rataratanya relatif rendah.
Tabel 3. Deskriptif Persentase Pengelolaan Proses Belajar-Mengajar

\begin{tabular}{|l|r|r|r|r|}
\hline $\begin{array}{l}\text { No. } \\
\text { Item }\end{array}$ & Kepsek & Guru & TU & Rerata \\
\hline 6 & $91.53 \%$ & $88.56 \%$ & $78.81 \%$ & $83.69 \%$ \\
7 & $79.24 \%$ & $75.42 \%$ & $78.81 \%$ & $77.12 \%$ \\
\hline Rerata & $85.38 \%$ & $81.99 \%$ & $78.81 \%$ & $80.40 \%$ \\
\hline
\end{tabular}

Kendala utama pelaksanaan proses belajar mengajar (PBM) adalah: 1) Terbatasnya sarana dan media pembelajaran, 2) Jika media sudah tersedia, ada sebagian guru yang enggan menggunakan/memanfaatkan, 3) Kualitas SDM para guru yang masih perlu ditingkatkan, serta 4) Masih kuatnya paradigma lama yang dianut guru, yaitu guru aktif dan siswa pasif. Beberapa saran yang dikemukakan pihak sekolah terkait dengan pelaksanaan PBM antara lain adalah: 1) perlu adanya pelatihan pengembangan kemampuan guru, utamanya tentang peningkatan kualitas PBM, 2) perlu adanya peningkatan bantuan sarana/fasilitas dari pemerintah daerah/ pusat, termasuk bantuan buku-buku ajar bagi para siswa.

\section{Pengelolaan Ketenagaan Pelaksanaan}

Berdasarkan Tabel 4 dapat diketahui bahwa pengelolaan ketenagaan pada sekolah secara umum termasuk kategori baik, dimana persentase rata-ratanya sebesar 78,37\%. Terdapat 12 item pertanyaan yang mengungkap aspek ketenagaan ini. Jika ditelusuri lebih jauh, ternyata jawabannya cukup bervariasi. Ada yang termasuk kategori sangat baik $(>85 \%)$, baik ( $>70 \%-85 \%)$, dan cukup baik ( $>60 \%-70 \%$ ).

Kegiatan yang termasuk kategori sangat baik antara lain: memberikan kesempatan kepada guru dan tenaga kependidikan untuk meningkatkan kemampuan, studi lanjut atau pelatihan (item no. 11 dan 24); mengembangkan hubungan kerja sesama guru dan sesama tenaga kependidikan (item no. 14); mengembangkan hubungan kerja antara kepala sekolah, guru dan tenaga kependidikan (item no. 15); dan pembinaan kepala sekolah terhadap guru dan staf (item no. 25).

Kegiatan yang termasuk kategori baik antara lain: melakukan analisis kebutuhan guru dan 
Tabel 4. Deskriptif Persentase Pengelolaan Ketenagaan

\begin{tabular}{|l|r|r|r|r|}
\hline $\begin{array}{l}\text { No. } \\
\text { Item }\end{array}$ & Kepsek & Guru & TU & Rerata \\
\hline 8 & $82.20 \%$ & $79.24 \%$ & $82.20 \%$ & $80.72 \%$ \\
9 & $82.20 \%$ & $77.12 \%$ & $80.08 \%$ & $78.60 \%$ \\
10 & $35.59 \%$ & $30.51 \%$ & $37.71 \%$ & $34.11 \%$ \\
11 & $91.95 \%$ & $88.98 \%$ & $88.14 \%$ & $88.56 \%$ \\
12 & $75.85 \%$ & $66.10 \%$ & $64.83 \%$ & $65.47 \%$ \\
13 & $75.85 \%$ & $69.92 \%$ & $71.61 \%$ & $70.76 \%$ \\
14 & $87.71 \%$ & $89.83 \%$ & $91.95 \%$ & $90.89 \%$ \\
15 & $91.10 \%$ & $92.37 \%$ & $91.53 \%$ & $91.95 \%$ \\
16 & $84.75 \%$ & $81.78 \%$ & $81.78 \%$ & $81.78 \%$ \\
24 & $90.68 \%$ & $85.59 \%$ & $89.83 \%$ & $87.71 \%$ \\
25 & $88.98 \%$ & $86.86 \%$ & $86.44 \%$ & $86.65 \%$ \\
26 & $88.98 \%$ & $82.20 \%$ & $84.32 \%$ & $83.26 \%$ \\
\hline Rerata & $81.32 \%$ & $77.54 \%$ & $79.20 \%$ & $78.37 \%$ \\
\hline
\end{tabular}

tenaga kependidikan (item no. 8); melakukan perencanaan terhadap kebutuhan guru dan tenaga kependidikan (item no. 9); melakukan evaluasi kinerja guru dan tenaga kependidikan (item no. 16), dan pembinaan kepala sekolah terhadap guru dan staf (item no. 26).

Kegiatan yang termasuk kategori cukup baik adalah item no. 12 tentang pemberian reward (penghargaan) kepada guru atau tenaga kependidikan yang berprestasi, dimana rerata persentasenya $65,47 \%$. Pada sisi lain, dalam hal pemberian punishment (sanksi/hukuman) bagi guru dan tenaga kependidikan secara kategori analisis termasuk baik, namun sebetulnya persentasenya rendah $(70,76 \%)$.

Khusus item no.10 rerata persentasenya sebesar 34,11\% bukanlah menggambarkan kondisi yang sebenarnya, karena item ini berisi tentang pertanyaan pelaksanaan rekrutmen guru dan tenaga kependidikan yang ditujukan khusus untuk responden dari sekolah swasta, sementara responden dari sekolah negeri tidak perlu menjawab (skor 0), sehingga persentase hasil perhitungannya menjadi rendah.

Terdapat banyak kendala yang berhasil diungkap dalam hal pengelolaan ketenagaan. Kendala-kendala tersebut adalah: 1) penempatan guru dan tenaga kependidikan kurang sesuai dengan analisis kebutuhan yang dilakukan sebelumnya, 2) beban mengajar antar guru tidak merata, ada yang berlebihan jam mengajarnya, sementara guru lain kurang, 3) khusus pada SMK, kesulitan mendapatkan guru yang sesuai dengan bidang keahlian yang dibutuhkan, 4) untuk sekolah swasta, anggaran biaya yang bersumber dari SPP terbatas, 5) sebagian guru kurang berminat melanjutkan studi karena merasa sudah tua, 6) belum adanya pedoman standar tentang evaluasi bagi guru dan tenaga kependidikan.

Beberapa saran yang dikemukakan pihak sekolah terkait dengan pengelolaan ketenagaan adalah: 1) penempatan guru (PNS) agar sesuai dengan kebutuhan sekolah (Sekolah Negeri), 2) perlu adanya bantuan guru (PNS) untuk sekolah swasta, 3) guru yang swasta yang diangkat menjadi PNS jangan dipindah ke sekolah negeri, 4) pemerintah perlu memberikan bantuan/subsidi bagi sekolah swasta sehingga insentif guru swasta lebih memadai, 5) perlu adanya bantuan biaya studi atau beasiswa bagi guru-guru yang berminat melanjutkan studi, dan 6) perlu adanya pedoman yang jelas tentang evaluasi bagi guru dan tenaga kependidikan, serta 7) pemerintah/ dinas pendidikan perlu terlibat dalam memberikan reward atau punishment.

\section{Pengelolaan Fasilitas Pelaksanaan}

Pengelolaan fasilitas dapat dikatakan berjalan dengan baik, dimana rata-rata jawaban responden adalah $80,19 \%$. Dari empat item pertanyaan, item no. 18 dan 19 persentasenya relatif lebih kecil $(78,81 \%$ dan $78,18 \%)$. Item ini berisi tentang pengadaan dan perawatan fasilitas sekolah (mesin, peralatan, perlengkapan). Hasil lengkap perhitungan disajikan pada tabel 5 .

Tabel 5. Deskriptif Persentase Pengelolaan Fasilitas

\begin{tabular}{|l|r|r|r|r|}
\hline $\begin{array}{l}\text { No. } \\
\text { Item }\end{array}$ & Kepsek & Guru & TU & Rerata \\
\hline 17 & $83.47 \%$ & $82.63 \%$ & $83.05 \%$ & $82.84 \%$ \\
18 & $80.08 \%$ & $79.66 \%$ & $77.97 \%$ & $78.81 \%$ \\
19 & $79.66 \%$ & $77.97 \%$ & $78.39 \%$ & $78.18 \%$ \\
20 & $82.63 \%$ & $81.78 \%$ & $80.08 \%$ & $80.93 \%$ \\
\hline Rerata & $81.46 \%$ & $80.51 \%$ & $79.87 \%$ & $80.19 \%$ \\
\hline
\end{tabular}

Kendala utama dalam pengelolaan fasilitas adalah terkait dengan terbatasnya anggaran. Disatu sisi jenis kebutuhan terhadap pengelolaan 
maupun pengadaan fasilitas cukup banyak dan beragam, namun sumber-sumber pembiayaan terbatas, apalagi untuk sekolah swasta. Saran yang dikemukakan pihak sekolah adalah: 1) perlu adanya bantuan anggaran maupun fasilitas dari pemerintah daerah maupun pusat, baik untuk sekolah negeri maupun swasta, misalnya dalam bentuk block grant, 2) supaya sekolah diberi kebebasan dalam menghimpun dana dari orangtua/masyarakat, dan 3) perlu adanya alokasi anggaran biaya untuk bantuan sekolah dalam APBD yang disusun pemerintah.

\section{Pengelolaan Keuangan Pelaksanaan}

Berbeda dengan aspek atau variabel sebelumnya yang rerata persentasenya relatif tinggi, pada aspek ini reratanya relatif rendah, yaitu $70,87 \%$. Secara kategorikal, termasuk "baik" (>70\% - 85\%), namun sebetulnya lebih dekat ke kategori "cukup baik" (>60\% - 70\%). Jika ditelusuri, terdapat dua item dimana reratanya cukup berbeda mencolok. Item no. 21 tentang pengelolaan/penganggaran keuangan sekolah secara mandiri persentasenya cukup tinggi, yaitu $83,05 \%$. Sementara itu item no. 22 tentang kegiatan-kegiatan yang mendatangkan penghasilan sekolah (income generating activities) persentasenya tergolong rendah $(58,69 \%)$, dimana hal ini mencerminkan aspek penggalian dana oleh sekolah secara mandiri belum berjalan dengan baik.

Pada item no. 22 tentang kegiatan-kegiatan yang mendatangkan penghasilan sekolah (income generating activities), apabila dilihat berdasarkan jenis sekolahnya, dapat diketahui bahwa persentase pada SMK lebih besar daripada SMA. Hal ini menunjukkan bahwa kegiatan penggalian sumber dana di SMK berjalan dengan baik.

Tabel 6. Deskriptif Persentase Pengelolaan Keuangan

\begin{tabular}{|l|r|r|r|r|}
\hline $\begin{array}{l}\text { No. } \\
\text { Item }\end{array}$ & Kepsek & Guru & TU & Rerata \\
\hline 21 & $88.14 \%$ & $83.90 \%$ & $82.20 \%$ & $83.05 \%$ \\
22 & $58.47 \%$ & $62.71 \%$ & $54.66 \%$ & $58.69 \%$ \\
\hline Rerata & $73.31 \%$ & $73.31 \%$ & $68.43 \%$ & $70.87 \%$ \\
\hline
\end{tabular}

Kendala utama dalam hal keuangan adalah, sebagian besar menyatakan bahwa anggaran atau dana yang ada, baik yang berumber dari pemerintah maupun masyarakat (SPP siswa, bantuan orang tua) masih kurang jika dibandingkan dengan kebutuhan yang harus dipenuhi. Beberapa saran yang diberikan pihak sekolah antara lain: 1) pemerintah perlu membuat klasifikasi sekolah berdasarkan kondisi sekolah atau daerah, 2) pihak sekolah supaya diberi kebebasan dalam menghimpun dana dari masyarakat (siswa/orangtua siswa), 3) pemerintah perlu meningkatkan bantuan/subsidi (block grant), dan 4) kebijakan sekolah dalam hal penarikan SPP jangan diintervensi dengan kebijakan pemerintah tentang sekolah gratis.

\section{Pelayanan Siswa}

\section{Pelaksanaan}

Dalam hal pelayanan terhadap siswa, secara umum termasuk kategori "baik" walaupun persentasenya relatif rendah $(73,36 \%)$. Terdapat empat item dalam aspek ini dimana rerata persentasenya terdapat perbedaan yang cukup signifikan. Pada item no. 23 tentang pelayanan penerimaan siswa baru, dan item no. 27 tentang pelayanan bagi siswa yang melanjutkan studi, rerata persentasenya relatif tinggi, masing-masing sebesar $89,41 \%$ dan $80,30 \%$.

Namun dua item lainnya, yaitu no. 28 tentang bantuan bagi siswa yang mencari pekerjaan, dan item no. 29 tentang fasilitasi atau kegiatan yang mengurusi alumni, persentasenya relatif kecil, masing-masing sebesar $66,31 \%$ dan $70,34 \%$.

Tabel 7. Deskriptif Persentase Pelayanan Siswa

\begin{tabular}{|l|r|r|r|r|}
\hline $\begin{array}{l}\text { No. } \\
\text { Item }\end{array}$ & Kepsek & Guru & TU & Rerata \\
\hline 23 & $87.71 \%$ & $88.98 \%$ & $89.83 \%$ & $89.41 \%$ \\
27 & $81.78 \%$ & $79.66 \%$ & $80.93 \%$ & $80.30 \%$ \\
28 & $69.92 \%$ & $63.98 \%$ & $68.64 \%$ & $66.31 \%$ \\
29 & $62.71 \%$ & $57.63 \%$ & $57.20 \%$ & $57.42 \%$ \\
\hline Rerata & $75.53 \%$ & $72.56 \%$ & $74.15 \%$ & $73.36 \%$ \\
\hline
\end{tabular}

Beberapa kendala yang terkait dengan pelayanan siswa adalah: 1) latar belakang siswa heterogen atau beragam, sehingga kebijakan yang ditempuh tidak dapat memuaskan semua pihak, 2) fasilitas yang dimiliki sekolah masih kurang atau jumlahnya terbatas, 3) keterbatasan tenaga yang mengurusi tentang pelayanan siswa 
secara khusus. Saran yang dikemukakan pihak sekolah antara lain: 1) perlu adanya peningkatan bantuan fasilitas yang dibutuhkan sekolah, 2) perlu penambahan tenaga guru sehingga pelayanan terhadapa siswa dapat optimal, 3) perlu ditingkatkannya dukungan orangtua, masyarakat, maupun pemerintah, serta 4) kerjasama dengan dunia usaha dan industri (DUDI) perlu ditingkatkan.

\section{Hubungan Sekolah-Masyarakat Pelaksanaan}

Hubungan sekolah dengan masyarakat secara keseluruhan belum memberikan hasil yang menggembirakan, hal ini nampak dari jawaban responden dimana rata-ratanya sebesar $70,27 \%$. Secara kategorikal termasuk "baik" (>70\% - 85\%), namun sebetulnya lebih dekat ke kategori "cukup baik" (>60\% - 70\%). Pada aspek ini antara lain mengungkap tentang keterlibatan masyarakat dalam kegiatan sekolah maupun dukungan moral dan finansial masyarakat kepada sekolah.

Tabel 8. Deskriptif Persentase Hubungan Sekolah-Masyarakat

\begin{tabular}{|l|r|r|r|r|}
\hline $\begin{array}{l}\text { No. } \\
\text { Item }\end{array}$ & Kepsek & Guru & TU & Rerata \\
\hline 30 & $74.15 \%$ & $72.88 \%$ & $69.49 \%$ & $71.19 \%$ \\
31 & $71.61 \%$ & $67.80 \%$ & $70.76 \%$ & $69.28 \%$ \\
32 & $72.88 \%$ & $70.34 \%$ & $70.34 \%$ & $70.34 \%$ \\
\hline Rerata & $72.88 \%$ & $70.34 \%$ & $70.20 \%$ & $70.27 \%$ \\
\hline
\end{tabular}

Pihak sekolah mengakui bahwa hubungan antara sekolah dengan masyarakat belum berjalan secara optimal. Hal ini disebabkan oleh kurang adanya kepedulian dari masyarakat terhadap sekolah. Kepedulian yang kurang ini tercermin dari beberapa hal, misalnya dalam hal dukungan dana, kebijakan/program, maupun kerjasama kegiatan. Saran yang diberikah pihak sekolah antara lain: 1) perlu adanya peningkatan peran komite sekolah sebagai wujud kerjasama sekolah-masyarakat, 2) perlu ditingkatkannya sosialisasi program dari sekolah ke masyarakat, misalnya melalui pertemuan berkala dengan orangtua siswa, dan 3) pihak sekolah perlu mengkaji/menempuh pendekatan baru terhadap masyarakat sehingga lebih efektif.

\section{Pengelolaan Iklim Sekolah Pelaksanaan}

Tabel 9. Deskriprif Persentase Pengelolaan Iklim Sekolah

\begin{tabular}{|l|r|r|r|r|}
\hline $\begin{array}{l}\text { No. } \\
\text { Item }\end{array}$ & Kepsek & Guru & TU & Rerata \\
\hline 33 & $83.47 \%$ & $83.47 \%$ & $75.85 \%$ & $79.66 \%$ \\
34 & $80.51 \%$ & $79.66 \%$ & $78.39 \%$ & $79.03 \%$ \\
35 & $84.75 \%$ & $84.75 \%$ & $84.32 \%$ & $84.53 \%$ \\
36 & $87.29 \%$ & $86.86 \%$ & $83.90 \%$ & $85.38 \%$ \\
37 & $84.32 \%$ & $87.29 \%$ & $83.63 \%$ & $84.96 \%$ \\
38 & $86.02 \%$ & $86.02 \%$ & $82.20 \%$ & $84.11 \%$ \\
39 & $80.93 \%$ & $78.81 \%$ & $80.93 \%$ & $79.87 \%$ \\
40 & $86.02 \%$ & $86.02 \%$ & $83.90 \%$ & $84.96 \%$ \\
\hline Rerata & $84.16 \%$ & $84.11 \%$ & $81.51 \%$ & $82.81 \%$ \\
\hline
\end{tabular}

Berdasarkan Tabel 9 di atas dapat diketahui bahwa pengelolaan iklim sekolah dapat dikatakan berjalan baik, persentase rataratanya relatif tinggi, yaitu $82,81 \%$. Dari delapan item yang ada, rerata jawaban dari masing-masing item juga tidak terdapat perbedaan yang mencolok, demikian juga jawaban yang diberikan oleh ketiga kelompok responden (kepala sekolah, guru, dan TU).

Terdapat banyak faktor yang dapat menghambat terciptanya iklim atau suasana sekolah yang kondusif. Faktor-faktor tersebut adalah: prasarana atau kondisi fisik sekolah, misalnya sekolah yang belum mempunyai pagar; anggaran biaya yang terbatas, sehingga kemampuan sekolah untuk memenuhi kebutuhan yang diinginkan juga terbatas; serta dukungan atau tanggung jawab dari pihak siswa, guru, serta masyarakat dalam upaya menciptakan iklim sekolah yang kondusif masih kurang. Beberapa saran yang dikemukakan pihak sekolah adalah: 1) perlu adanya peraturan teknis tentang organisasi sekolah yang rinci, 2) perlu ditingkatkan tentang koordinasi atau kerjasama dengan semua pihak, utamanya dengan masyarakat sekitar, dan 3) perlu ditingkatkan bantuan anggaran biaya bagi sekolah, dengan harapan kebutuhan sekolah terpenuhi dan PBM pun berjalan sesuai dengan yang diharapkan.

Pada pelaksanaan MBS, hasil penelitian secara umum (tanpa membedakan jenis dan status sekolah) dapat dilihat pada Tabel 10 di bawah. 
Tabel 10. Rekapitulasi Pelaksanaan MBS

\begin{tabular}{|c|c|c|c|}
\hline No. & Aspek/Variabel & $\begin{array}{r}\text { Rata- } \\
\text { rata } \\
(\%)\end{array}$ & $\begin{array}{l}\text { Kate } \\
\text { gori }\end{array}$ \\
\hline 1 & $\begin{array}{l}\text { Perencanaan dan Evaluasi } \\
\text { Sekolah }\end{array}$ & 83,55 & Baik \\
\hline 2 & Pengelolaan Kurikulum & 78,60 & Baik \\
\hline 3 & $\begin{array}{l}\text { Pengelolaan Proses Belajar } \\
\text { Mengajar }\end{array}$ & 80,40 & Baik \\
\hline 4 & Pengelolaan Ketenagaan & 78,37 & Baik \\
\hline 5 & Pengelolaan Fasilitas & 80,19 & Baik \\
\hline 6 & Pengelolaan Keuangan & 70,87 & Baik \\
\hline 7 & Pelayanan Siswa & 73,36 & Baik \\
\hline 8 & Hubungan Sekolah- & & \\
\hline & Masyarakat & 70,27 & Baik \\
\hline 9 & Pengelolaan Iklim Sekolah & 82,81 & Baik \\
\hline \multicolumn{2}{|c|}{ Rata-rata } & 77,60 & Baik \\
\hline
\end{tabular}

Berdasarkan Tabel 10, dapat ditegaskan kembali bahwa dari sembilan aspek pelaksanaan MBS, besarnya persentase jawaban responden cukup bervariasi. Rata-rata besarnya persentase jawaban responden adalah $77,60 \%$, sehingga hal ini menunjukkan bahwa pelaksanaan MBS di sekolah menengah (SMA dan SMK) secara umum berjalan dengan baik.

Walaupun secara kategorikal kesembilan aspek termasuk "baik", jika dilihat lebih jauh dapat diketahui bahwa terdapat beberapa aspek atau variabel yang perlu mendapat perhatian. Berdasarkan besarnya persentase, terdapat tiga variabel yang persentasenya dibawah persentase rata-rata $(77,60 \%)$ yaitu variabel tentang: 1$)$ pengelolaan keuangan $(70,87 \%), 2)$ pelayanan siswa $(73,36 \%)$, dan 3$)$ hubungan sekolahmasyarakat $(70,27 \%)$.

Jika ditelusuri lebih jauh, dapat diketahui dalam hal apa saja kelemahan pelaksanaan MBS tersebut berdasarkan item-item jawaban yang ada. Untuk aspek atau variabel pengelolaan keuangan, kelemahan terletak dalam hal penggalian sumber dana melalui kegiatan-kegiatan yang dapat mendatangkan keuntungan (income generating activities). Besarnya persentase ratarata item ini hanya 58,69\%, hal ini menunjukkan bahwa pihak sekolah (terutama SMK) belum memanfaatkan potensi sumberdaya sekolah yang dimiliki. Selain itu hal ini juga menunjukkan ketergantungan sekolah terhadap pihak lain (pemerintah, orangtua siswa, masyarakat) masih tinggi.

Kelemahan yang kedua adalah tentang pelayanan terhadap siswa. Berdasarkan uraian sebelumnya diketahui bahwa hal ini disebabkan kelemahan pihak sekolah dalam dua hal, yaitu: 1) bantuan terhadap siswa dalam memasuki dunia kerja $(66,31 \%)$ dan 2) fasilitasi dan mengurusi kegiatan alumni $(57,42 \%)$.

Rendahnya pelayanan siswa dalam memasuki dunia kerja terjadi terutama untuk Sekolah Menengah Kejuruan (SMK) karena lulusan SMK memang dipersiapkan untuk memasuki dunia kerja. Sementara itu pelayanan dalam hal melanjutkan sekolah, terutama untuk Sekolah Menengah Umum (SMU atau SMA) berjalan relatif baik $(80,30 \%)$.

Dalam hal kegiatan yang melibatkan alumni yang persentasenya rendah tersebut, perlu mendapatkan perhatian semua pihak tanpa memandang jenis dan status sekolah. Bagi SMK, alumni dapat dimanfaatkan dalam perluasan jaringan kerja atau membantu alumni dalam memasuki dunia kerja, dan bagi SMA, dapat dimanfaatkan dalam membantu lulusan menempuh studi lanjut maupun memasuki dunia kerja.

Satu aspek lagi yang pelaksanaannya tergolong kurang sesuai harapan adalah tentang hubungan sekolah-masyarakat. Semua item yang mengungkap aspek ini persentasenya dibawah rata-rata $(<77,60 \%)$. Hal ini menunjukkan memang aspek ini perlu mendapatkan perhatian dan perlu dicari pemecahan atau jalan keluarnya. Kelemahan dalam hal hubungan sekolahmasyarakat juga terkait dengan aspek keuangan yang juga lemah, yaitu kurangnya perlibatan masyarakat dalam pembiayaan sekolah.

Selain tiga aspek pelaksanaan MBS yang kurang sesuai harapan (persentase dibawah ratarata $77,60 \%)$, terdapat dua aspek yang persentasenya sedikit diatas rata-rata, dan hal ini juga menunjukkan pelaksanaannya kurang optimal. Kedua aspek tersebut adalah: 1) Pengelolaan Kurikulum (78,60\%), dan 2) Pengelolaan Ketenagaan (78,37\%).

Berdasarkan kajian lebih jauh, dapat diketahui bahwa untuk aspek pengelolaan kurikulum, sekolah masih lemah dalam hal pengembangan kurikulum muatan lokal $(76,48 \%)$. 
Hal ini berlaku untuk semua jenis dan status sekolah, karena baik di SMA maupun SMK, statusnya negeri maupun swasta diterapkan kurikulum muatan lokal.

Dalam aspek ketenagaan, kelemahan yang menonjol adalah dalam hal pemberian reward (penghargaan) bagi yang berprestasi $(65,47 \%)$, dan tentang pemberian punishment (sanksi/ hukuman) bagi yang melanggar peraturan atau melakukan perbuatan tercela $(70,67 \%)$. Mengingat persentasenya yang relatif rendah, hal ini menunjukkan bahwa pemberian reward and punishment memang belum berjalan dengan baik di sekolah.

Dalam hal pelaksanaan MBS, aspek yang cukup menonjol adalah terbatasnya anggaran biaya dan sarana atau fasilitas sekolah. Terkait dengan kendala di atas, saran yang cukup menonjol dari pihak sekolah adalah agar pemerintah (pusat atau daerah) dapat meningkatkan bantuan/subsidi keuangan maupun fasilitas kepada sekolah, tanpa memandang perbedaan jenis maupun status sekolah.

\section{Simpulan dan Saran Simpulan}

Berdasarkan uraian dan pembahasan hasil penelitian, dapat diambil beberapa kesimpulan yaitu terdapat: 1) sembilan aspek pelaksanaan MBS yang diungkap dengan rata-rata besarnya persentase jawaban responden adalah $77,60 \%$, sehingga hal ini menunjukkan bahwa pelaksanaan MBS di sekolah menengah secara umum berjalan dengan baik; 2) empat aspek yang persentasenya diatas persentase rata-rata dan diatas $80 \%$, yaitu tentang: a. Perencanaan dan evaluasi sekolah $(83,55 \%)$, b. Pengelolaan proses belajar mengajar $(80,40 \%)$, c. Pengelolaan fasilitas $80,19 \%)$, dan d. Pengelolaan iklim sekolah $(82,81 \%) ; 3)$ dua aspek yang persentasenya sedikit diatas persentase rata-rata (77,60\%) serta dibawah $80 \%$, yaitu tentang: a. Pengelolaan kurikulum $(78,60 \%)$, dan b. Pengelolaan ketenagaan $(78,37 \%) ; 4)$ tiga aspek yang persentasenya dibawah persentase ratarata $(77,60 \%)$ yaitu tentang: a. Pengelolaan keuangan $(70,87 \%)$, b. Pelayanan siswa $(73,36 \%)$, dan c. Hubungan sekolah-masyarakat $(70,27 \%) ; 5)$ Pada aspek pengelolaan kurikulum, kelemahan terletak dalam hal pengembangan kurikulum muatan lokal dimana persentase rataratanya sebesar $76,48 \% ; 6$ ) aspek ketenagaan, kelemahan yang menonjol adalah dalam hal pemberian reward (penghargaan) bagi yang berprestasi $(65,47 \%)$, dan pemberian punishment (sanksi/hukuman) bagi yang melanggar peraturan atau melakukan perbuatan tercela dengan persentase rata-rata $70,76 \%$; 7) aspek pengelolaan keuangan, kelemahan terletak dalam hal penggalian sumber dana melalui kegiatan-kegiatan yang dapat mendatangkan keuntungan (income generating activities) dengan persentase rata-rata hanya $58,69 \%$; 8) aspek pelayanan terhadap siswa, kelemahan pihak sekolah terletak dalam dua hal, yaitu: a. Bantuan terhadap siswa dalam memasuki dunia kera $(66,31 \%)$ dan b. Fasilitasi dan mengurusi kegiatan alumni $(57,42 \%) ; 9)$ aspek hubungan sekolahmasyarakat, kelemahan disebabkan oleh rendahnya keterlibatan masyarakat dalam kegiatan sekolah maupun dukungan moral dan finansial masyarakat kepada sekolah; 10) Dalam hal kendala pelaksanaan MBS, aspek yang paling menonjol adalah terbatasnya anggaran biaya, minimnya fasilitas yang dimiliki sekolah, serta masih rendahnya kualitas SDM, misalnya kesulitan mendapat guru yang mengajar sesuai dengan kompetensinya; 11) Saran yang cukup menonjol dari pihak sekolah adalah agar pemerintah (pusat atau daerah) dapat meningkatkan bantuan/ subsidi keuangan maupoun fasilitas kepada sekolah, terutama untuk sekolah swasta, serta perlu sering diadakan pelatihan-pelatihan atau workshop bagi guru guna meningkatkan kemampuan dan wawasannya.

\section{Saran}

Berdasarkan kesimpulan penelitian, dapat disampaikan beberapa rekomendasi, yaitu: 1) Aspekaspek MBS yang telah berjalan dengan baik perlu dipertahankan dan terus ditingkatkan, antara lain tentang: a. Perencanaan dan evaluasi sekolah, b. Pengelolaan proses belajar mengajar, c. Pengelolaan fasilitas, dan $d$. Pengelolaan iklim sekolah; 2) Perlu keterlibatan semua pihak, antara lain guru, masyarakat, serta pemerintah dalam hal ini Dinas Pendidikan setempat guna mengembangkan dan menerapkan kurikulum 
muatan lokal yang paling cocok dengan kondisi sekolah; 3) Agar prinsip reward atau punishment berjalan dengan baik, perlu ketegasan pihak kepala sekolah namun perlu didukung dengan instrumen dan payung hukum/peraturan yang jelas serta dukungan instansi vertikal diatasnya (Dinas Pendidikan Daerah dan Pusat); 4) Pihak sekolah harus mulai memikirkan dan selanjutnya melaksanakan kegiatan-kegiatan yang dapat mendatangkan keuntungan (income generating activities) sehingga dapat membantu meringankan kebutuhan biaya sekolah atau mengurangi ketergantungan bantuan biaya dari pihak lain; 5) Pelayanan terhadap siswa, utamanya tentang bantuan terhadap siswa dalam memasuki dunia kerja (khususnya bagi siswa SMK) dan kegiatan yang melibatkan alumni harus ditingkatkan oleh pihak sekolah; dan 6) Pihak sekolah harus aktif menggandeng/melibatkan masyarakat dalam setiap program kegiatan sehingga rasa tanggung jawabnya meningkat, dan pada akhirnya nanti dukungan moral dan finansial masyarakat kepada sekolah akan meningkat.

\section{Pustaka Acuan}

Bank Dunia. 1998. Bank Dunia dan Pendidikan di Indonesia, Jakarta: Bank Dunia

Daman. 2001. Pelaksanaan Manajemen Peningkatan Mutu Berbasis Sekolah (MPMBS) di SLTP Kota Semarang. Laporan Penelitian, FIP Unnes.

Hamonangan, S. 2004. Kesiapan Pengelolaan dan Pengembangan Manajemen Berbasis Sekolah (MBS) dalam Rangka Pelaksanaan Otonomi Daerah di Kabupaten Grobogan. Semarang: Sari PenelitianLemlit UNNES.

Indarno, Jasman. 2002. Kontribusi Penerapan Berbasis Sekolah Terhadap Kualitas Penyelenggaraan Pendidikan Tingkat Dasar di Jawa Tengah. Tesis. Semarang: Program Pasca Sarja Universitas Diponegoro.

Jaeni, Muhammad and Kuntoro, Sodiq A. 2005. Pola Manajemen Keuangan Berbasis Sekolah dan Hubungannya dengan Kinerja Sekolah. Jurnal Penelitian dan Evaluasi. Nomor 1, Tahun VII, 2005. Yogyakarta: PPS-UNY

Rahma Sugihartati. 2004. Implementasi dan Kendala Pelaksanaan Manajemen Berbasis Sekolah di Jenjang SD. Jurnal Penelitian Dinamika Sosial. Vol.5 No. 3 Desember 2004. Surabaya: Lembaga Penelitian UNAIR.

Sallis, Edward. 1993. Total Quality Management in Education. London: Kogan Page Limited. 